\title{
Rent seeking and the economics of corruption
}

\author{
Toke S. Aidt ${ }^{1}$
}

(C) The Author(s) 2016. This article is published with open access at Springerlink.com

\begin{abstract}
The paper studies the influence of Tullock (West Econ J 5:224-232, 1967 ) and the rent-seeking literature more generally on the study of corruption. The theoretical corruption literature with its emphasis on principal-agent relationships within government and rent creation by corruption politicians has largely, but not entirely, overlooked that contestable rents encourage unproductive use of real resources in seeking these rents. As a consequence, the literature underestimates the value of corruption control and the cost of corruption itself.
\end{abstract}

Keywords Rent seeking · Corruption · Bribes

\section{JEL Classification D72}

\section{Introduction}

For the modern reader, it is quite an eye-opener to go back and read Gordon Tullock's paper "The welfare costs of tariffs, monopolies, and theft" published in 1967 in the Western Economic Journal (now Economic Inquiry). The paper is very short and to the point, uses a few simple diagrams, and does not exhibit a single equation or a statistical table of any kind. Yet, it contains one of the most powerful new insights emerging from twentieth century economic thought, laid out clearly

I would like to thank Roger Congleton, Arye Hillman and the participants in the Gordon Tullock Memorial Conference at George Mason University, October 2015, for helpful comments and suggestions.

Toke S. Aidt

toke.aidt@econ.cam.ac.uk

1 Faculty of Economics, University of Cambridge, Sidgwick Avenue, Cambridge CB3 9DD, UK 
towards the end of the paper. The insight, of course, is that the social cost of government policy (monopoly, transfers, regulation, etc.) is much greater than suggested by the calculation of Harberger triangles and deadweight cost. The source of the extra cost is the contesting of rents created by the policies by potential beneficiaries expending real resources. This, along with Tullock's (1980) paper on "Efficient rent seeking" started a huge literature on rent seeking - the term coined by Krueger (1974) for the activities described by Tullock. ${ }^{1}$

The purpose of this paper is to discuss the influence of the rent-seeking literature on the study of the economics of corruption. The terms "rent seeking" and "corruption" are often used interchangeably. Closer inspection of the academic literature, however, reveals that the two literatures have proceeded in parallel to a surprisingly large extent. I shall argue that this is unhelpful and that both the rentseeking and the corruption literature can benefit from each other.

The rest of the paper is organized as follows. Section 2 develops a taxonomy that helps set the stage for the rest of the analysis. Section 3 provides a brief overview of the theoretical corruption literature. Section 4 evaluates the influence of the rentseeking literature on the study of corruption. Section 5 inquiries into the influence of the corruption literature on the study of rent seeking. Section 6 engages with the relationship between empirical research on corruption and rent seeking. Section 7 provides some concluding remarks.

\section{The core concepts, definitions and taxonomy}

In this section, I briefly review the two main insights from Tullock (1967) and propose a general taxonomy that can help clarify the link between corruption and rent seeking.

\subsection{The core ideas of the rent-seeking literature}

It is useful, I think, to start by clarifying the main ideas and concepts, even if they are familiar to most readers. The rent-seeking literature embodies two core ideas, which can both be found in Tullock (1967). The insights are:

1. The missiles seek heat hypothesis: A contestable rent induces rent-seeking activities aimed at capturing the rent. These activities involve unproductive use of real resources and cause a social loss.

2. The invertability hypothesis: Rent-seeking costs are, by and large, unobserved but by applying contest theory and assumptions about the behaviour of rent seekers, the size of the social cost can be inferred from the value of the contestable rent.

\footnotetext{
1 The rent-seeking literature has been surveyed by Nitzan (1994), Tollison (1997), Congleton et al. (2008), Hillman (2013), and Long (2013 [2015]). The papers in Congleton and Hillman (2015) summarize the different dimensions of the rent-seeking literature.
} 
Examples of contestable rents are abundant: assigning monopoly rights, protectionist trade policies, privileged budget allocations, income transfers, national resource rights, and so on. The distinguishing feature making a rent contestable is that ex ante-i.e., before it is assigned to any particular economic agent-it is up for grabs. This is what makes it rational for potential beneficiaries to expend resources in contesting rents.

Contestable rents differ from contestable profits, which trigger socially productive activities (Buchanan 1980). Contestable profits play an important and efficiency enhancing role in the allocation of resources in a capitalist market economy. Economic agents have an incentive to expand into markets with profits and to innovate to create profits; this improves resource allocation, expands output of the economy and increases aggregate welfare.

Many contestable rents are created and protected by government policy and government officials and politicians are gatekeepers who regulate who gains access to the rents. This is what Tullock had in mind. In this case, economic agents cannot contest the rent by shifting resources directly into production of the underlying good or service. Instead, they are motivated to invest time, effort and other real resources - to engage in rent-seeking activities-in attempts to secure either the initial assignment of the right to the rent or in ousting others from their position of privilege. These resources are employed unproductively but have social value in alternative employment.

All this is largely unobserved and certainly not recorded by any statistical agency and reported to the public. This makes it hard to know how large these loses really are. Fortunately, the second insight - the invertability hypothesis-can help: the social loss can be inferred through contest-models from the size of the contestable rent. It is, in other words, possible to "invert" the process and use the size of the observable rents to infer the unobserved social cost of rent seeking. A very extensive literature on rent dissipation, including Tullock's (1980) paper on efficient rent seeking, has subsequently demonstrated that the possible relations between the observable rent to the underlying rent-seeking expense are complex and contingent on many assumptions or influences. ${ }^{2}$

\subsection{Definitions and taxonomy}

In order to examine the influence that the two core insights from the rent-seeking literature have had on the corruption literature, the starting point must be to settle on definitions of what the two social phenomena are and to develop a workable taxonomy that can help us organize the material.

The standard definition of "rent seeking" is the quest for privileged benefits from government [see, for example, Hillman (2013)]. While there is general agreement on this definition, it has proved much harder to converge on a widely accepted definition of corruption. ${ }^{3}$ An often used definition of corruption amongst economists

\footnotetext{
${ }^{2}$ See, e.g., Hillman and Samet (1987) on all-pay auctions, Ursprung (1990) on rents as public goods, and Aidt and Hillman (2008) on rents that endure over time and may require re-contesting.

3 Williams (2000) contains a collection of social science articles that dwell more deeply into the definitional issues.
} 
is "sale by government officials of government property for private gain" (Shleifer and Vishny 1993) or situations where "the power of public office is used for personal gain in a manner that contravenes the rules of the game" (Jain 2001).

Taking these definitions at face value, it is clearly possible to have rent seeking without corruption and vice versa. If, for example, a government official is charged with allocating mobile phone licenses and the rules specify that he must select the company that makes the "most convincing case for efficient service delivery" and if he follows this rule to the best of his ability, then there is no corruption. Yet, there will be a lot of rent seeking. The mobile phone companies will expend vast resources on making their case for being the best for the job. Conversely, it is also possible to have corruption without rent seeking. Suppose, for example, that one of the companies pays a bribe to obtain the license without any checks on its ability to deliver the services efficiently (and no one else makes any effort to show their fitness for the job), then we clearly have a situation of corruption but without any real resources have been used unproductively in rent-seeking activities. This line of reasoning, however, gives the impression that corruption and rent seeking are entirely different social phenomena and that is misleading and unhelpful. The problem is that the definition of corruption used in the economics literature is too narrow.

It is more fruitful, as suggested by Lambsdorff (2002, p. 98), to employ a broader definition. Thus, let me define corruption as a special means by which private agents may seek to pursue their interest in competition for preferential treatment by government officials or politicians and where the "means" are valued by the recipient. The primary example of a "special means" is a bribe-a monetary payment in return for preferential treatment. The use of personal contacts (favouritism) according to the principle "you help me and I will help you" is another example.

This definition alongside the definition of rent seeking itself highlights an important consideration. It matters a lot from a social point of view, if the "means" of seeking preferential treatment involves the outputs or income from the production process or it involves the direct use of factors of production. In the first case, the available factors of production are employed to produce output and generate income to the factor owners, i.e., the economy is on the production frontier (maybe on a second best frontier, but nonetheless on the frontier). Some of the income thus generated may be used to seek rents and preferential treatment. This is the situation envisaged by much of the corruption literature. In the second case, factors of production, for example, labour, which could have been employed in production of output are deployed in the process of seeking rents-people who could become entrepreneurs become lobbyists. As a consequence, the economy produces below its production frontier and output and income is lost. This is the situation envisaged by the rent-seeking literature which is concerned with the efficiency losses due to unproductive use of resources in the quest for rents.

Using the definitions, corruption and rent seeking can be combined as instances of influence-seeking activities. Such activities can be distinguished along two dimensions: whether the gatekeeper who assigns the rent benefits from the influence-seeking activities and whether the influence-seeking activity involves a 
transfer of income (bribe) or unproductive use of resources. This gives rise to the two-by-two taxonomy in Table 1a and the illustrative examples in Table 1b.

According to this taxonomy, pure corruption refers to the case where competition for preferential treatment is such that the gatekeeper benefits from the influenceseeking expenses/activities in the way of a costless income transfer from the beneficiary to the gatekeeper. Pure rent seeking refers to the situation in which competition for preferential treatment is such that the gatekeeper does not benefit from the influence-seeking expenses/activities, which represent unproductive use of factors of production. The case of impure corruption emerges if the income transfer is associated with a transaction cost such that the value of the income transfer to the gatekeeper is lower than the cost to those paying the transfer. Impure rent seeking emerges if the unproductive use of factors of production in seeking influence may, in fact, benefit the gatekeeper.

There are, of course, a whole raft of intermediate cases and many other distinctions can be made (corruption is restricted to a few competitors while rent seeking is open to all; corruption is not legal, while rent seeking is, etc.), but the two-dimensional taxonomy is, at the very least, helpful in clarifying the link between the rent-seeking and corruption literature. Most of the corruption literature is concerned with situations where the gatekeeper gains and the influence-seeking activity represents an income transfer. Bribery is the classical example of this which is often viewed as a costless transfer (e.g., Rose-Ackerman 1975; Lui 1985). In reality, even bribery is associated with transaction costs (e.g., Tirole 1992). This reduces the value of the bribe for the gatekeeper and in the limit, makes it worthless. The classical rent-seeking literature, including the examples given by Tullock (1967) and the analysis in Hillman and Samet (1987) and many other papers on rent dissipation is about pure rent seeking: real resources are being employed in seeking, say, a government-sponsored monopoly rent, which is assigned without any gain to the official who assigns it. However, it is possible to envisage cases in which the gatekeeper may gain. The literature on contest design, for example, engages with the possibility that the rent-seeking expense is, in fact, valued by the government official who assigns the underlying rent (Gradstein and Konrad 1999; Epstein and Nitzan 2015). This leads to what I call contestable bribery in Table $1 \mathrm{~b}$.

Table 1 Taxonomy of influence-seeking activities

\begin{tabular}{lll}
\hline Means/gains & Gatekeeper does not gain & Gatekeeper gains \\
\hline $\begin{array}{l}\text { (a) General taxonomy } \\
\text { Income transfer }\end{array}$ & Impure corruption & \\
Factor of production & Pure rent seeking & $\begin{array}{l}\text { Pure corruption } \\
\text { Impure rent seeking }\end{array}$ \\
(b) Examples of taxonomy & & \\
Income transfers & Bribes with transaction costs & Bribes with no transaction costs \\
& Tirole (1992) & Rose-Ackerman (1975) \\
Factor of production & Advocacy, argumentation & Contestable bribery \\
& Tullock (1967) & Gradstein and Konrad (1999)
\end{tabular}




\section{Overview of the corruption literature}

The theoretical corruption literature has evolved along two main branches. ${ }^{4}$ They are

1. The helping hand type of corruption: Corruption arises when a benevolent principal delegates decision making power to a non-benevolent agent. The level of corruption depends on the costs and benefits of designing optimal institutions. Corruption is optimal.

2. The grabbing hand type of corruption: Corruption arises because nonbenevolent government officials introduce inefficient policies in order to extract rents from the private sector. The level of corruption depends on the incentives embodied in existing (often suboptimal) institutions and policies. Corruption is not optimal.

The first branch of literature has its origin in the law and economics and in the organisational economics literatures, with classical contributions by Becker and Stigler (1974), Rose-Ackerman (1975), and Tirole (1992, 1994) and, more recent contributions, by Laffont and Guessan (1999), Acemoglu and Verdier (2000), Dabla-Norris (2002), and Dhami and Al-Nowaihi (2007) amongst many others. A typical "helping hand" scenario, which we shall use as a heuristic devise below, is environmental regulation. Un-internalised and socially harmful externalities provide a prima facie case for government intervention and a benevolent government would want to impose a correction. In practice, the task of doing so is delegated to a bureaucracy. The officials of the bureaucracy will amongst other things be tasked with checking that the polluting firms abide by the regulations. The problem, however, is that it is impossible for the government to monitor the officials perfectly. This leaves room for collusion between the firms and the officials. Any given official may agree to accept a bribe for not reporting violations of the regulations. Or the regulator may simply come to identify with the regulated firm. The benevolent government tries to avoid this by designing institutions (monitoring, wage structures, penalties) to maximise social welfare, but it is costly to design such institutions. It may, therefore, be optimal to accept a residual of corruption and rule violation. That is, corruption within this conception is, in fact, optimal in a second best sense.

The second strand of literature starts from the Tullock dictum "people are people" and does not assume any degree of benevolence in the conduct of the government. Examples of contributions to this literature include Shleifer and Vishny (1993), Bliss and di Tella (1997), and Aidt and Dutta (2008). A typical "grabbing hand" scenario, which we shall also explore below, is entry regulation. Suppose that there are no good welfare economics reasons for restricting entry into an industry. Yet, a corruptible government official or politician may nonetheless introduce a

\footnotetext{
4 Aidt (2003) lists two additional categories, called efficient corruption and self-reinforcing corruption. For the purpose of evaluating the influence of the rent-seeking literature on the corruption literature, it is, however, sufficient to zoom in on the two main categories listed in the text. For other classifications, see Tanzi (1998), Rose-Ackerman (1999) or Jain (2001).
} 
license system that restricts entry. The reason is that such regulation creates rents through artificial scarcity. As a consequence, potential producers in the industry is willing to pay a bribe to obtain a license. A leviathan-type politician would, then, issue the bribe maximising number of licences and collect the largest possible bribe income. In practice, however, institutional constraints may impose some limits of this sort of behaviour. The level of corruption depends on given institutional structures, culture, and history and is, in general, sub-optimal. Moreover, the type of corruption is endogenous to the political regime. Charap and Harm (2002) point out that this is a natural consequence of the predatory strategies that "rulers" operating under different constraints employ to extract rents from the economy. For example, in a dictatorship, a corrupt and low-paid bureaucracy, either of the competitive or monopolistic type, can at the same time help the dictator to maintain power and to extract rents from the economy. In contrast, in a functioning democracy, the preferred vehicle for rent extraction becomes interest group contributions to political campaigns.

\section{The influence of the rent-seeking literature on the study of corruption}

We can use the two examples developed above to evaluate the influence of the rentseeking literature on the study of the economics of corruption. In the "helping hand" scenario, a corruptible public official may share a rent with the firm that he is meant to regulate by accepting a bribe in return for turning a blind eye to environmental violations. The rent itself is created by asymmetric information and imperfect monitoring. There is a social loss involved because of socially undesirable environmental damage. This is, however, optimal given the costs and benefits of designing incentives. It is important for this conclusion that the information rent is not contestable and the influence-seeking activity-offering a bribe-is a pure transfer. It is also important that the bribe does not by itself involve a social loss, although one could imagine that transaction costs would reduce the value of the bribe received below the utility cost of paying it. Yet, the point remains that the receiver, the government official, values the bribe. In this type of model, influence seeking is limited to what I termed pure (or at worst impure) corruption in Table 1a. It is simply a transfer of resources from one set of agents to another. There is no social loss involved over and above the fact that public policy is distorted.

In the grabbing hand scenario, rents have to be created by the public official before bribes can be collected. This is done by introducing a license system which restricts entry to economic activity and creates artificial scarcity. This, by itself, involve a social loss. Yet, the public official has a private incentive to do this because he can extract some or all of the rent from the would-be producers who are willing to offer a bribe to be "assigned" the scarcity rent. Again, the bribe is a pure transfer between producers and public officials, and, given and take, transaction costs, it does not constitute a social loss in and by itself. Although the rent created by each licence is contestable, the structure of the contest is such that competition takes place through bribery. It does not involve any persuasion, advocacy or any other activity which would involve "burning" real resources with positive shadow 
prices and which might not benefit the public official personally in the process of seeking the rent conferred by the production licence.

The core insight from Tullock's seminal paper that these approaches (and the corruption literature more generally) have not taken up is the notion of "rent contestability". Consider the case of monopoly rents created by entry restrictions. Tullock (1967) points out that, if the monopoly rent is contestable, it will attract real resources, which he assumed was equal to its value. This adds the "Tullock rectangle" to the standard deadweight cost of monopoly. If, in contrast, the monopoly right were secured by paying the public official in charge a bribe, it would appear that the additional cost would vanish: the bribe is "just" a transfers from one party to another. However, this misses the point. Posner (1975) puts it like this: "It might seem that where monopoly is obtained by bribery of government officials, the additional loss of monopoly [the rent-seeking cost] would be eliminated since a bribe is a pure transfer. In fact, however, bribery merely shifts the monopoly profit to the officials receiving the bribe and draws real resources into the activity of becoming the official who is in the position to receive these bribes" (p. 82). ${ }^{5}$

This is a very important point which has been largely ignored in the corruption literature, but not entirely. Hillman and Katz (1987) take up the baton in their paper "Hierarchical structure and the social costs of bribes and transfers". 6 Their starting point is that agents who seek a rent may use bribery - transfers of income-to gain access to the rent. While these bribes do not (necessarily) involve any social loss, the bribe income stream may be contestable. This happens when bribe income is a prize that can be won through a contest for particular positions in government, i.e., the positions to which the bribes accrue are themselves contestable. In the environmental regulation scenario, for example, being appointed to oversee regulated firms may be open to many potential officials who all know that obtaining the appointment will allow them to extract bribes from the firms that they oversee. If so, a pure rent-seeking contest will follow and the resources employed in winning that contest may well be time and effort-factors of production that could be used productively. Consequently, the rent created by the corruption opportunity offered by asymmetric information and imperfect monitoring, not only represents a case of pure corruption. It also represents a case of pure rent seeking because the position in the government bureaucracy is a contestable rent. The situation becomes even worse when influence seeking takes place within a hierarchy in which lowerdown officials pass some of the bribe income on to higher-up officials. In this case, each position becomes a contestable rent with an associated social cost of contestability (Hillman and Katz 1987). Another reason why the rent-seeking cost is likely to be large in this case is that the rents are private, i.e., the prize of obtaining a position in the hierarchy is a private revenue stream. Ursprung (1990) has shown that the distinction between private and public-goods rents is very important for the

\footnotetext{
5 Krueger (1974, pp. 292-293) makes a similar point.

${ }^{6}$ Hillman and Ursprung (2000) describe nested contests in which outsiders compete to be insiders who compete directly for rents. Political culture determines the openness of the contests to outsiders.
} 
overall social cost. The degree of rent dissipation is much larger with private than with public-goods rents.

The point about contestability is also taken up in a sequence of studies of misallocation of talent and corruption, although the connection to the rent-seeking literature is not always made explicit. The general idea in this literature is that talented people can be employed as private sector entrepreneurs (or in some other productive job) or as government bureaucrats. Positions in the public sector offer corruption possibilities and government officials can benefit personally from the rents they control (created by, for example, collusion allowed by asymmetric information as in the example above). Controlling these rents is a contestable prize and agents will seek employment in the government sector to gain access to them. If the most talented people seek these jobs, there will be misallocation of talent: individuals who should have become productive entrepreneurs become rent seekers (in the sense of pure rent seeking) instead. The social costs of rent seeking is, then, the economic consequences of this misallocation of talent, which could be lower growth or income, plus, of course, the policy distortion created by bribery in the first place.

Murphy et al. (1991) develop this logic in a model of allocation of talent in which the government serves no particular purpose. However, government jobs offer the possibility to create and extract rents to the personal benefit of the holder of the job (which is their definition of corruption). The analysis emphasizes that talent is often general and talented individuals can be successful in many different jobs, including in jobs that offer pure corruption possibilities and in entrepreneurial jobs. More able people may be able to extract more rents, and if this advantage is sufficiently large, the most talented will seek jobs in the public sector because those jobs offer corruption opportunities. The social cost is too little innovation and lower economic growth [see also Murphy et al. (1993)].

The underlying premise of this analysis is that more able people are good at both rent seeking and productive activities. This appears plausible: many lobbyists are very clever, and could have put their talent to productive use in the biotech or some other frontier industry rather than use their abilities in the lobbying industry. However, this is not the only reason why corruption opportunities in the public sector can lead to misallocation of talent. Acemoglu and Verdier $(1998,2001)$ point to another more subtle mechanism. In their analysis, the government bureaucracy has a socially valuable purpose, namely to enforce contracts that support productive investment. This, however, creates corruption possibilities since individual bureaucrats may decide not to enforce a contract in return for a payment from the party that benefits. Anticipating this makes investment unprofitable ex ante and too little or no investment will be undertaken. The benevolent government may try to solve this problem by paying efficiency wages. This, however, generates a social cost because it attracts individuals to the public sector with no comparative advantage in that sector. The rent-seeking cost is indirect in this model: it is not so much the fact that government jobs offer corruption possibilities that is the source of the problem. Rather, it is the benevolent government's attempt to control corruption by paying above market wages that induces the misallocation of talent. 


\section{The influence of the corruption literature on the study of rent seeking}

While the corruption literature, leaving the exceptions noted above aside, could learn from the rent-seeking literature, it is not a one-way street. The rent-seeking literature can also learn from the corruption literature, or, at least, part of it.

Most importantly, the "grabbing hand" corruption literature emphasises rent creation: corrupt officials create rents which they extract for themselves via bribery. They do so by introducing artificial scarcity via licenses, permissions, cumbersome procedures, etc. In contrast, in the rent-seeking literature, the rents are often (but obviously not always) taken as given; they are there for "whatever reason". It is plain that the incentive of a public official to create artificial scarcity depends critically on whether he or she can subsequently benefit from the rent thus created. Government officials have little incentive to create rents if they cannot benefit from them (Hillman 2015). Bribery allows officials the maximum flexibility in capturing the rent they have created. As emphasized by Lambsdorff (2002), this makes corruption, understood as influence-seeking activities from which officials personally benefit, particularly harmful to society: corruption possibilities encourage rent creation. If, instead, rent creation triggers influence-seeking activities which do not directly benefit the official and may even be costly to him or her because it involves costly engagement with lobbyists and special interests, then the incentive to create the rent in the first place is decreased.

In short, corruption encourages rent creation because it allows the creator of the rent to benefit personally. To quote Tullock (1996, p. 8) in his discussion of corruption in nineteenth century China, "the official actually write the laws with the intent of being bribed to permit people to avoid carrying out the law." In contrast, if bribery for some reason becomes impossible or unattractive (e.g., because of better control structures) and, as a consequence, most rents will be contested in ways that do not benefit the official, then he or she might decide that it is time to repeal the regulation that generated the rent in the first place and be deterred from thinking up ways to create new rents. An implication, then, is that bribery is particularly harmful from a social point of view. It underlies the incentive for officials to create rents. This is socially harmful in itself because it involves creating artificial scarcity and this creates deadweight losses. On top of that, bribery and corruption more broadly maximise the risk of triggering costly contests related to obtaining the positions in government that enable the bribes to be collected.

While the consequences of the symbiotic relationship between rent creation and corruption has yet to be fully explored in the rent-seeking literature in general, the literature on contest design, initiated by Gradstein and Konrad (1999) and explored in Mealem and Nitzan (2015) amongst others, provides the foundation for a bridge between the two literatures. It studies how a contest might be designed if the "rentseeking effort" is beneficial to the contest designer who then has an interest in maximising "effort". This incentive is particularly strong if the "effort" is a bribe transfer to the contest designer. A promising research programme would be to explore more deeply the interplay between corruption, rent creation and contest design. 


\section{The empirics of corruption and rent seeking}

The past 30 years have seen a massive empirical research effort aimed at understanding the causes and consequences of (pure) corruption (see, e.g., Paldam 2002; Lambsdorff 2005; Svensson 2005; Treisman 2007; Aidt 2011a). This research agenda has been fuelled by cross country data on corruption perceptions and more recently by individual or firm level survey data on experienced corruption. These types of data have attracted a fair amount of critique and rightly so. ${ }^{7}$ Yet, the empirical corruption literature clearly points to substantial economic costs of corruption. Mauro (1995), for example, finds a small negative growth effect and a large negative effect of corruption on investment. Subsequent research has shown that the growth effect interacts with the underlying quality of institutions (Aidt et al. 2008; Méndez and Sepúlveda 2006; Méon and Weill 2010) and that corruption has a detrimental impact on sustainable development (Aidt 2011b). Other studies have shown that corruption increases inequality (Gupta et al. 2002) and distorts fiscal and monetary policy and the composition of government spending (e.g., Mauro 1998; Hessami 2014; Dimakou 2015). Expenditure tracking studies undertaken in many countries have demonstrated how vast amounts of public resources intended for schools and other public spending programmes simply disappear and never reach the intended beneficiaries (Reinikka and Svensson 2004).

Unlike the study of corruption, empirical research on rent seeking can hardly be said to be booming. ${ }^{8}$ The existing research efforts have partly been guided by the invertability hypothesis and partly by attempts to measure rent seeking costs directly. Krueger (1974), Posner (1975) and Cowling and Mueller (1978) pioneered the indirect method based on the invertability hypothesis. Krueger (1974) estimated that the welfare loss from trade intervention in India and Turkey in the 1960s was between 7 and $15 \%$ of GNP. Posner (1975) estimated the rent seeking cost associated with monopoly regulation in the USA to be between 5 and $32 \%$ of industry sales. Cowling and Mueller (1978) found that the total welfare cost of monopoly in the US and the UK, respectively, was 13 and $7 \%$ of gross corporate product. These studies and others like them assume full rent dissipation. The theoretical literature on rent seeking contests shows that this assumption is only valid in special cases and that the degree of dissipation depends on the contest function, on risk preferences, on the nature of the prize being sought, and on many other features. Employing the full dissipation assumption is, therefore, likely to inflate the cost estimates. Lopez and Pagoulatos (1994) is a rare example of a study that estimates the degree of rent dissipation. They find, in an application to US trade policy, that $67 \%$ of the value of the available rent is dissipated and estimate the total social loss of trade barriers in the US to be $12.5 \%$ of the value of domestic consumption. Hazlett and Michaels (1993) also estimate dissipation ratios. They explore a natural experience induced by a cellular telephone licence lottery in the 1980 s in the USA and find that the ratio was $31.2 \%$ on average.

\footnotetext{
7 See the critical discussion in Kaufmann et al. (2006).

${ }^{8}$ Del Rosal (2011) offers a critical survey of the empirical rent-seeking literature.
} 
An alternative approach is to estimate the social cost of rent seeking simply by adding observable expenditures on rent seeking related activities up. A typical finding is that the actual money spent on lobbying (in the USA) is low relative to the value of the rents at stake - an observation Tullock (1988) himself made when he rhetorically asked why the total amount of resources going into politics appear to be small relative to the value of the prizes that can potentially be won. ${ }^{9}$ Others have gone further than counting lobbying expenses and added more expenditures to the rent seeking bill (e.g., expenditures on advertising, on crime prevention, or on property rights disputes) or tried to estimate rent seeking costs from "excess" presence of certain types of economic activities in capital cities (e.g., sit-down restaurants). The estimates emerging from this type of research vary a lot in size, from 0.2 to $23.7 \%$ of GDP (Del Rosal 2011, Table 2). The fundamental problem with this approach clearly is that it requires an up-front judgement about what constitutes rent seeking costs, and doing that objectively is hard, if not impossible.

The empirical rent-seeking literature suggests that rent dissipation is incomplete, and that the total rent seeking cost, therefore, could be a lot smaller than the value of the rents. In contrast, the empirical corruption literature points to substantial welfare costs of corruption and strongly suggests that corruption is a major obstacle to economic development. Of course, one could take the view that corruption costs in practise are correlated with rent seeking costs. However, doing so would diverge attention away from the very important task of quantifying the true cost of rent seeking. One way out of this conundrum is to base empirical research on rent seeking more firmly on rent seeking theory and to build structural models that can be matched to observable data on policy outcomes, campaign contributions, employment in the lobbying industry, etc. and in that way help us back out the true cost of public policy.

\section{Conclusion}

It is surprising that the corruption and rent-seeking literatures have not crisscrossed more than it appears to have been the case. After all, they are both concerned with what I have called influence-seeking activities and there is clearly scope for fruitful cross fertilization. The corruption literature, both the branch that focuses on principal-agent relationships within government and the branch that focusses on leviathan-type governments, has largely ignored the "missiles seek heat hypothesis" of rent seeking, i.e., the notion that the presence of contestable rents elicits socially costly activities aimed at winning the rents. The consequences of this are two-fold. First, the literature underestimates the value of corruption-control policies. The overriding objective of the law and economics and organisational economics

\footnotetext{
9 Mixon (2002), for example, finds that interest group contributions related to obtaining social security funds in the USA amount to only $0.2 \%$ of the value of the potential rents. Goldberg and Maggi (1999) estimate the weight given to social welfare relative to special interest groups in the setting of US trade policy. Their results suggest that the influence of special interests is very small, which, again, suggests that the welfare cost of rent seeking is of limited importance. Hillman and Ursprung (2016) discuss reasons why there appear to be less rent seeking and less rent dissipation than might be expected.
} 
literature on corruption is precisely to devise and evaluate such policies. A fruitful research project would be integrate the notion of contestable rents and the associated rent-seeking cost into the principal-agent models of corruption and to reconsider existing results about socially optimal levels of corruption. Second, the literature underestimates the social cost of corruption. Insofar as corruption is conceptualized as a costless transfer of income from one party to another, it may appear that corruption is a social problem only because it leads to policy distortions and because it leads to inequitable and unfair allocations of public resources and funds. The rent-seeking literature would insist adding Tullock rectangles on the debit side. We just need to quantify them.

Open Access This article is distributed under the terms of the Creative Commons Attribution 4.0 International License (http://creativecommons.org/licenses/by/4.0/), which permits unrestricted use, distribution, and reproduction in any medium, provided you give appropriate credit to the original author(s) and the source, provide a link to the Creative Commons license, and indicate if changes were made.

\section{References}

Acemoglu, D., \& Verdier, T. (1998). Property rights, corruption and the allocation of talent: A general equilibrium approach. Economic Journal, 108, 1381-1403.

Acemoglu, D., \& Verdier, T. (2000). The choice between market failure and corruption. American Economic Review, 90(1), 194-211.

Aidt, T. S. (2003). Economic analysis of corruption: A survey. Economic Journal, 113, F633-F652.

Aidt, T. S. (2011a). The causes of corruption. Journal for Institutional Comparison, 9(2), 15-19.

Aidt, T. S. (2011b). Corruption and sustainable development. In S. Rose-Ackerman \& T. Søreide (Eds.), International handbook on the economics of corruption (Vol. 2, pp. 3-51). Cheltenham: Edward Elgar.

Aidt, T. S., \& Dutta, J. (2008). Policy compromises: Corruption and regulation in a democracy. Economics and Politics, 20(3), 335-360.

Aidt, T. S., Dutta, J., \& Sena, V. (2008). Governance regimes, corruption and growth: Theory and evidence. Journal of Comparative Economics, 36(2), 195-220.

Aidt, T. S., \& Hillman, A. L. (2008). Enduring rents. European Journal of Political Economy, 164, 509-533.

Becker, G., \& Stigler, G. (1974). Law enforcement, malfeasance and the compensation of enforcers. Journal of Legal Studies, 3, 1-19.

Bliss, C., \& di Tella, R. (1997). Does competition kill corruption? Journal of Political Economy, 105, 1001-1023.

Buchanan, J. (1980). Rent seeking and profit seeking. In J. M. Buchanan, R. D. Tollison \& G. Tullock (Eds.), Towards a theory of the rent-seeking society (pp. 3-15). College Station, TX: Texas A\&M Press. Reprinted in R.D. Congleton, A.L. Hillman \& K.A. Konrad (Eds.) (2008), Forty years of research on rent seeking 1-The theory of rent seeking (pp. 55-67). Heidelberg: Springer.

Charap, J., \& Harm, C. (2002). Institutionalized corruption and the Kleptocratic state. In G. T. Abed \& S. Gupta (Eds.), Governance, corruption, economic performance, Chapter 6 (pp. 135-158). Washington, D.C.: The International Monetary Fund.

Congleton, R. D., \& Hillman, A. L. (Eds.). (2015). Companion to the political economy of rent seeking. Cheltenham: Edward Elgar.

Congleton, R. D., Hillman, A. L., \& Konrad, K. A. (2008). Forty years of research on rent seeking: An overview. In R.D. Congleton, A.L. Hillman \& K.A. Konrad (Eds.) (2008), Forty years of research on rent seeking 1-The theory of rent seeking (pp. 1-42). Heidelberg: Springer.

Cowling, K., \& Mueller, D. C. (1978). The social costs of monopoly power. Economic Journal, 88, 727-748. Reprinted in R.D., Congleton, A.L. Hillman \& K.A. Konrad (Eds.) (2008), Forty years of 
research on rent seeking 2-Applications: Rent Seeking in Practice (pp. 67-88). Heidelberg: Springer.

Dabla-Norris, E. (2002). A game theoretical analysis of corruption in bureaucracies. In G. T. Abed \& S. Gupta (Eds.), Governance, corruption, economic performance, Chapter 5 (pp. 111-134). Washington, D.C.: The International Monetary Fund.

Del Rosal, I. (2011). The empirical measurement of rent-seeking costs. Journal of Economic Surveys, 25(2), 298-325.

Dhami, S., \& Al-Nowaihi, A. (2007). Corruption and the provision of public output in a hierarchical asymmetric information relationship. Journal of Public Economic Theory, 9(4), 727-755.

Dimakou, O. (2015). Bureaucratic corruption and the dynamic interaction between monetary and fiscal policy. European Journal of Political Economy, 40(Part A), 57-78.

Epstein, G. S., \& Nitzan, S. I. (2015). Contestable policies. In R. D. Congleton \& A. L. Hillman (Eds.), Companion to the political economy of rent seeking (pp. 53-72). Cheltenham: Edward Elgar.

Goldberg, P. K., \& Maggi, G. (1999). Protection for sale: An empirical investigation. American Economic Review, 89(5), 1135-1155.

Gradstein, M., \& Konrad, K. A. (1999). Orchestrating rent seeking contests. Economic Journal, 109 (458), 536-545. Reprinted in R.D. Congleton, A.L. Hillman \& K.A. Konrad (Eds.) (2008), Forty years of research on rent seeking 1-The theory of rent seeking (pp. 571-580). Heidelberg: Springer.

Gupta, S., Davoodi, H. R., \& Alonso-Terme, R. (2002). Does corruption affect income inequality and poverty? Economics of Governance, 3, 23-45. Reprinted in G. T. Abed \& S. Gupta (Eds.), Governance, corruption, economic performance, Chapter 17 (pp. 458-486). Washington, D.C.: The International Monetary Fund.

Hazlett, T. W., \& Michaels, R. J. (1993). The cost of rent-seeking: evidence from cellular telephone license lotteries. Southern Economic Journal, 59, 425-435.

Hessami, Z. (2014). Political corruption, public procurement, and budget composition: Theory and evidence from OECD countries. European Journal of Political Economy, 34, 372-389.

Hillman, A. L. (2013). Rent seeking. In M. Reksulak, L. Razzolini, \& W. F. I. I. Shughart (Eds.), The Elgar companion to public choice (2nd ed., pp. 307-330). Cheltenham: Edward Elgar.

Hillman, A. L. (2015). Rent seeking as political economy. In R. D. Congleton \& A. L. Hillman (Eds.), Companion to the political economy of rent seeking (pp. 10-16). Cheltenham: Edward Elgar.

Hillman, A. L., \& Katz, E. (1987). Hierarchical structure and the social costs of bribes and transfers. Journal of Public Economics, 34, 129-142. Reprinted in R.D. Congleton, A.L. Hillman \& K.A. Konrad (Eds.) (2008), Forty years of research on rent seeking 1-The theory of rent seeking (pp. 523-536). Heidelberg: Springer.

Hillman, A. L., \& Samet, D. (1987). Dissipation of contestable rents by small numbers of contenders. Public Choice, 54, 63-82. Reprinted in R.D. Congleton, A.L. Hillman \& K.A. Konrad (Eds.) (2008), Forty years of research on rent seeking 1-The theory of rent seeking (pp. 165-184). Heidelberg: Springer.

Hillman, A. L., \& Ursprung, H. W. (2000). Political culture and economic decline. European Journal of Political Economy 16, 189-213. Reprinted in R.D., Congleton, A.L. Hillman \& K.A. Konrad (Eds.) (2008), Forty years of research on rent seeking 2-Applications: Rent seeking in practice (pp. 219-243). Heidelberg: Springer.

Hillman, A. L., \& Ursprung, H. W. (2016). The political economy of income distribution: Where are the rent seekers? Constitutional Political Economy (this issue).

Jain, A. K. (2001). Corruption: A review. Journal of Economic Surveys, 15(1), 71-121.

Kaufmann, D., Kraay, A., \& Mastruzzi, M. (2006). Measuring governance using cross-country perceptions data. In S. Rose-Ackerman (Ed.), International handbook on the economics of corruption (pp. 52-104). Cheltenham: Edward Elgar.

Krueger, A. O. (1974). The political economy of the rent-seeking society. American Economic Review, 64, 291-303. Reprinted in R.D. Congleton, A.L. Hillman \& K.A. Konrad (Eds.) (2008), Forty years of research on rent seeking 2-Applications: Rent seeking in practice (pp. 151-163). Heidelberg: Springer.

Laffont, J. J., \& Guessan, T. N. (1999). Competition and corruption in an agency relationship. Journal of Development Economics, 60, 271-295.

Lambsdorff, J. G. (2002). Corruption and rent seeking. Public Choice, 113(1-2), 97-125.

Lambsdorff, J. G. (2005). Consequences and causes of corruption: What do we know from a cross section of countries? Passau: University of Passau. 
Long, N. V. (2013).The theory of contest: A unified model and review of the literature. European Journal of Political Economy, 32, 161-181. Reprinted in R.D. Congleton \& A.L. Hillman (Eds.) (2015), Companion to the political economy of rent seeking (pp. 19-52) Cheltenham: Edward Elgar.

Lopez, R. A., \& Pagoulatos, E. (1994). Rent seeking and the welfare cost of trade barriers. Public Choice, $79,149-160$.

Lui, F. T. (1985). An equilibrium queuing model of bribery. Journal of Political Economy, 93, 760-781.

Mauro, P. (1995). Corruption and growth. Quarterly Journal of Economics, 110, 681-712.

Mauro, P. (1998). Corruption and the composition of government expenditure. Journal of Public Economics 69, 263-279. Reprinted in G. T. Abed \& S. Gupta (Eds.), Governance, corruption, economic performance, Chapter 9 (pp. 225-244). Washington, D.C.: The International Monetary Fund.

Mealem, Y., \& Nitzan, S. (2015). Contest effort. In R. D. Congleton \& A. L. Hillman (Eds.), Companion to the political economy of rent seeking (pp. 124-137). Cheltenham: Edward Elgar.

Méndez, F., \& Sepúlveda, F. (2006). Corruption, growth and political regimes: Cross country evidence. European Journal of Political Economy, 22(1), 82-98.

Méon, P.-G., \& Weill, L. (2010). Is corruption an efficient grease? World Development, 38(3), 244-259.

Mixon, F. G. (2002). Social security trust funds flows and the welfare cost of rent seeking. Applied Economics, 34, 975-979.

Murphy, K. M., Shleifer, A., \& Vishny, R. W. (1991). The allocation of talent: Implications for growth. Quarterly Journal of Economics, 106, 503-530.

Murphy, K. M., Shleifer, A., \& Vishny, R. W. (1993). Why is rent seeking so costly to growth? American Economic Review Paper and Proceedings, 83, 409-414. Reprinted in R.D. Congleton, A.L. Hillman \& K.A. Konrad (Eds.) (2008), Forty years of research on rent seeking 2-Applications: Rent seeking in practice (pp. 213-218). Heidelberg: Springer.

Nitzan, S. (1994). Modeling rent-seeking contests. European Journal of Political Economy, 10, 41-60.

Paldam, M. (2002). The cross-country pattern of corruption: Economics, culture and the seesaw dynamics. European Journal of Political Economy, 18(2), 215-220.

Posner, R. A. (1975). The social cost of monopoly and regulation. Journal of Political Economy, 83, 807-827. Reprinted in R.D. Congleton, A.L. Hillman \& K.A. Konrad (Eds.) (2008), Forty years of research on rent seeking 2-Applications: Rent seeking in practice (pp. 45-65). Heidelberg: Springer.

Reinikka, R., \& Svensson, J. (2004). Local capture: Evidence from a central government transfer program in Uganda. Quarterly Journal of Economics, 119(2), 679-705.

Rose-Ackerman, S. (1975). The economics of corruption. Journal of Public Economics, 4, 187-203.

Rose-Ackerman, S. (1999). Corruption and government, causes, consequences and reform. Cambridge: Cambridge University Press.

Shleifer, A., \& Vishny, R. W. (1993). Corruption. Quarterly Journal of Economics, 108, 599-618.

Svensson, J. (2005). Eight questions about corruption. Journal of Economic Perspectives, 19(3), 19-42.

Tanzi, V. (1998). Corruption around the world, causes, consequences, scope, and cures. IMF Staff Papers, 45 (4), 559-594. Reprinted in G. T. Abed \& S. Gupta (Eds.), Governance, corruption, economic performance, Chapter 2 (pp. 19-58). Washington, D.C.: The International Monetary Fund.

Tirole, J. (1992). Collusion and the theory of organization. In J. J. Laffont (Ed.), Advances in economic theory (sixth world congress Vol. 2). Cambridge: Cambridge University Press.

Tirole, J. (1994). The internal organisation of government. Oxford Economic Papers, 46, 1-29.

Tollison, R. D. (1997). Rent seeking. In D. C. Mueller (Ed.), Perspectives on public choice. A handbook (pp. 506-526). Cambridge: Cambridge University Press.

Treisman, D. (2007). What have we learned about the causes of corruption from ten years of crossnational empirical research? Annual Review of Political Science, 10, 211-244.

Tullock, G. (1967). The welfare cost of tariffs, monopolies, and theft. Western Economic Journal 5, 224-232. Reprinted in R.D. Congleton, A.L. Hillman \& K.A. Konrad (Eds.) (2008), Forty years of research on rent seeking 1-The theory of rent seeking ( $\mathrm{pp} .45-53)$. Heidelberg: Springer.

Tullock, G. (1980). Efficient rent seeking. In J. M. Buchanan, R. D. Tollison, \& G. Tullock (Eds.), Towards a theory of the rent-seeking society (pp. 97-112). College Station, TX: Texas A\&M Press. Reprinted in R.D. Congleton, A.L. Hillman \& K.A. Konrad (Eds.) (2008), Forty years of research on rent seeking 1-The theory of rent seeking (pp. 105-120). Heidelberg: Springer.

Tullock, G. (1988). Future directions for rent-seeking research. In C. K. Rowley, R. D. Tollison, \& G. Tullock (Eds.), The political economy of rent seeking. Boston: Kluwer.

Tullock, G. (1996). Corruption theory and practice. Contemporary Economic Policy, XIV, 6-13. 
Ursprung, H. W. (1990). Public goods, rent dissipation, and candidate competition. Economics and Politics 2, 115-132. Reprinted in R.D. Congleton, A.L. Hillman \& K.A. Konrad (Eds.) (2008), Forty years of research on rent seeking 1-The theory of rent seeking (pp. 329-346). Heidelberg: Springer.

Williams, R. (ed.). (2000). Explaining corruption. The politics of corruption (Vol. 1). Cheltenham: Edward Elgar. 